\title{
FASE DAN TUGAS PERKEMBANGAN ANAK SEKOLAH DASAR
}

\author{
${ }^{1}$ Fatma Khaulani, ${ }^{2}$ Neviyarni S, ${ }^{3}$ Irda Murni \\ 르eviyarni.suhaili@gmail.com, ${ }^{2}$ neviyarni.suhaili@gmail.com, ${ }^{3)}$ irdamurni241161@gmail.com
}

Prodi Pendidikan Dasar, Program PascaSarjana Universitas Negeri Padang

\begin{abstract}
ABSTRAK
Tulisan ini membahas serta menganalisis fase dan tugas-tugas perkembangan pada anak SD. Seperti yang kita ketahui, fase serta tugas perkembangan yang dimiliki oleh anak berbeda sesuai dengan kondisi perkembangan anak tersebut. Berdasarkan penelitan melalui kajian pustaka yang dilakukan, diperoleh hasil siswa sekolah dasar berada fase kanak-kanak akhir yang memiliki perkembangan dari segi fisik-motorik, kognisi, sosio-emosional, bahasa, dan moral keagamaan. Inilah yang menjadi sebuah alasan mengapa seorang pendidik atau calon pendidik perlu memikirkan fase pengembangan dan siswa sekolah dasar. Manfaat dari penelian ini adalah melalui pemahaman guru tentang tugas dan fase perkembangan siswa, dapat diantisipasi tentang berbagai upaya pengembangan, baik di sekolah rumah dan masyarakat, selain itu dengan mengetahui fase perkembangan siswa dapat menyesuaikan tugas-tugas perkembangan yang harus dikuasai siswa dengan fase perkembangannya.
\end{abstract}

Kata kunci: fase, tugas perkembangan, anak SD

\section{PHASE AND STAGES OF DEVELOPMENT FOR PRIMARY STUDENTS}

\author{
${ }^{1}$ Fatma Khaulani, ${ }^{2}$ Neviyarni S, ${ }^{3}$ Irda Murni \\ 1․ㅡeviyarni.suhaili@gmail.com, ${ }^{2}$ neviyarni.suhaili@gmail.com, ${ }^{3)}$ irdamurni241161@gmail.com \\ Prodi Pendidikan Dasar, Program PascaSarjana Universitas Negeri Padang
}

\begin{abstract}
This paper discusses and analyzes the phases and tasks of development in elementary school children. As we know, the development phases and tasks of the child are different according to the child's developmental conditions. Based on research through literature studies conducted, it was found that elementary school students were in the final childhood phase which had developments in terms of physical-motoric, cognition, socio-emotional, language, and religious morals. This is a reason why an educator or prospective educator needs to think about the development phase and elementary school students. The benefits of this study are through the teacher's understanding of the assignments and phases of student development, it can be anticipated about various development efforts, both at home schools and the community, in addition to knowing the phases of development students can adjust the development tasks that students must master with their developmental phases.
\end{abstract}

Kata kunci: phase, stages of development, primary student 


\section{PENDAHULUAN}

Usia tertentu setiap individu akan lebih cepat dan mudah memperoleh kecekatan dalam menguasai ketrampilan-ketrampilan tertentu, Di samping itu juga mempelajari pola tingkah laku tertentu sesuai dengan fase perkembangan yang dilewatinya. Untuk mencapai fase tertentu tersebut, pertumbuhan biologis merupakan dasar utama dalam pembentukan fase perkembangan seorang individu. Tingkat kematangan fisik dan mental pada setiap individu terjadi pada waktu dan tempo yang berbeda-beda. Ada yang cepat dan ada yang lambat. Setiap individu akan mengalami fase-fase perkembangan dalam hidupnya, yaitu: bayi, kanak-kanak, anak, remaja, dewasa, dan masa tua. Dari penjelasan yang telah dijabarkan, dapat ditarik kesimpulan bahwa fase perkembangan diartikan sebagai tahapan atau pembentukan tentang kehidupan individu yang di memiliki ciri khusus atau pola tingkah laku tertentu.

Kekuatan biologis individu dan kekuatan psikologis serta sosiologis menggiring individu menuju tugas perkembangan yang harus dikerjakannya dalam upaya usaha menuju individu yang berhasil. Dalam menjalani hidupnya, individu akan berusaha untuk melakukan tugas perkembangan yang sesuai dengan fase perkembangannya agar mereka mendapatkan kebahagiaan bagi kehidupan bermasyarakatnya. Setiap tahap atau fase pertumbuhan dan perkembangan memiliki tugas perkembangannya sendiri. Tugas ini akan tampak pada suatu masa tertentu dalam kehidupan individu. Keberhasilan dalam mencapai tugas tersebut akan membawa suatu rasa kebahagiaan dan keberhasilam dalam melakukan tugas pada fase berikutnya, sedangkan bila gagal dalam mencapai tugas itu akan membawa rasa kecewa dan ketidak bahagiaan dalam kehidupan bermasyarakat serta akan menemui kesulitan dalam tugas berikutnya.

Tugas-tugas pertumbuhan dan perkembangan akan muncul sesuai dengan fase perkembangan setiap indivu. Tugas ini merupakan kewajiban yang harus dilalui oleh setiap individu. Perkembangan yang muncul pada setiap waktu tertentu merupakan keharusan yang akan berlaku secara otomatis seperti kegiatan belajar keterampilan dalam menjalankan tugas-tugas perkembangannya.

Fase perkembangan anak akan sesuai dengan tugas perkembangan anak. Oleh karena itu, guru sebagai salah satu penggerak pendidikan harus bida menjadi fasilitator agar tugas 
perkembangan anak SD ini bisa sepenuhnya terpenuhi selain itu, guru harus mengadakan inovasi dalam pembelajaran agar tidak tertinggal dengan perkembangan anak SD.

\section{METODE PENELITIAN}

Pada tulisan ini metode yang digunakan dalam penelitian ini adalah metode studi kepustakaan (library research). Studi pustaka atau kepustakaan merupakan kegiatan pengumpulan data dari berbagai sumber bacaan. (Harahap, 2014).

Data yang digunakan dalam menyelesaikan penelitian ini berasal dari sumber berupa buku, jurnal serta artikel yang sesuai dengan penilitian ini.

\section{HASIL DAN PEMBAHASAN}

\section{Hasil Penelitian}

\section{Fase Perkembangan anak SD}

Perkembangan berkaitan dengan kepribadian yang terintegrasi. Anak sekolah dasar yang berusia diantara 6-11 tahun berada pada fase kanak-kanak tengah (Sumantri, 2014: 99).Fase kanakkanak tengah, anak memiliki kemampuan dasar berhitung, menulis, serta membaca. Fase perkembangan anak SD dapat dilihat dari beberapa aspek utama kepribadian individu anak, yaitu aspek 1) fisik-motorik, 2) kognisi, 3) sosio-emosional, 4) bahasa, dan 5) moral keagamaan yang akan Fase perkembangan anak dijelaskan sebagai berikut:

\section{Fisik-motorik}

Pertumbuhan fisik anak pada usia SD ditandai dengan anak menjadi lebih tinggi, berat, dan kuat dibandingkan pada saat anak berada di PAUD/TK, hal ini tampak pada perubahan sistem tulang, otot dan keterampilan gerak. Anak lebih aktif dan kuat untuk melakukan kegiatan fisik seperti berlari, memanjat,melompat, berenan dan kegiatan luar rumah lainnya. Kegiatan fisik ini dilakukan oleh anak dalam upaya melatih koordinasi, motorik, kestabilan tubuh maupun penyaluran energi yang tertumpuk. (Izzaty, 2008).

Perkembangan fisik anak SD lakilaki dan perempuan berbeda. Anak perempuan biasanya lebih ringan dan lebih pendek daripada anak laki-laki. (Slavin, 2011). Aspek perkembangan fisik-motorik ini berpengaruh terhadap aspek perkembangan lainnya, sebagai contoh, keadaan fisik anak yang kurang normal misalnya anak terlalu tinggi atau terlalu pendek, anak terlalu kurus atau gemuk akan mempengaruhi rasa kepercayaan diri anak. Rasa kepercayaan ini akan berkaitan 
dengan emosi, kepribadian, dan sosial anak (Latifa, 2017)

2. Kognisi

Aspek perkembangan kognisi merupakan perkembangan yang berhubungan dengan kemampuan kognitif yang dimiliki oleh anak, yakni kemampuan untuk berpikir dan memecahkan masalah. Anak usia sekolah dasar memiliki karakteristik berpikir yang khas. Cara berpikir mereka berbeda dengan anak pra sekolah dan orang dewasa. Cara mengamati lingkungan sekitar dan mengorganisasi dunia pengetahuan yang mereka dapatpun berbeda dengan anak prasekolah dan orang dewasa. Teori perkembangan Piaget merupakan salah satu teori perkembangan kognitif yang terkenal. Dalam teorinya, Piaget menjelaskan anak usia SD yang pada umumnya berusia 7 sampai 11 tahun, berada pada tahap ketiga dalam tahapan perkembangan kognitif yang dicetuskannya yaitu tahap operasional konkret. Pada tahap ini, anak dinilai telah mampu melakukan penalaran logis terhadap segala sesuatu yang bersifat konkret, tetapi anak belum mampu melakukan penalaran untuk hal-hal yang bersifat abstrak (Trianingsih, 2016).Anak usia SD akan mengalami perkembangan kognitif yang pesat. Anak akan mulai belajar membentuk sebuah konsep, melihat hubungan, dan memecahkan masalah terhadap situasi yang bersifat konkret. (Slavin, 2011). Untuk itu, Guru hendaknya dapat membangun suasana belajar yang konkret bagi anak sebagai guna memudahkan anak dalam berpikir logis serta dapat memecahkan masalah. (Trianingsih, 2016).

3. Perkembangan sosio-emosional.

Ciri khas dari fase ini ialah meningkatnya intensitas hubungan anak dengan teman-teman sebayanya serta ketergantungan anak terhadap keluarga menjadi berkurang. Pada fase ini hubungan atau kontak sosial lebih baik dari sebelumnya sehingga anak lebih senang bermain dan berbicara dalam lingkungan sosialnya. Dari penjelasan tersebut dapat disimpulkan bahwa teman sebaya memiliki peranan yang penting dalam perkembangan sosial anak, karena melalui teman sebaya anak bisa belajar dan mendapat informasi mengenai dunia anak di luar keluarga (Murni, 2017). Hal lainnya yang tampak pada fase ini ialah anak sudah mulai membentuk konsep diri sebagai anggota kelompok sosial di luar keluarga. Hubungan sosial anak dengan orang 
dewasa di luar keluarga memberikan pengaruh penting dalam pengembangan kepercayaan diri anak. Ketidakpercayaan diri pada anak akan timbul jika anak tidak mampu mengerjakan tugas seperti temannya. Dalam kegiatan pembelajaran peran guru sangat penting dalam menumbuhkan kepercayaan diri anak serta semangat berkarya sesuai dengan kemampuan masing-masing anak.

4. Perkembangan Bahasa

Bahasa merupakan suatu alat untuk berkomunikasi dalam suatu interaksi sosial. Perkembangan bahasa anak akan berkembang dari awal masa sekolah dasar dan mencapai kesempurnaan pada akhir masa remaja. Pada usia late primary (7-8 tahun), bahasa anak mengalami perkembangan yang sangat pesat. Anak telah memahami tata bahasa, sekalipun terkadang menemui kesulitan dan menunjukkan kesalahan tetapi anak dapat memperbaikinya. Anak telah mampu menjadi pendengar yang baik. Anak mampu menyimak cerita yang didengarnya, dan selanjutnya mampu mengungkapkan kempali dengan urutan dan susunan yang logis. Anak telah menunjukkan niatanya terhadap puisi, dan juga mampu mengungkapkan perasaan dan pikirannya dalam bentuk puisi. Anak memiliki kemampuan untuk memahami lebih dari satu arti, dan memperkaya kata menjadi sebuah humor. (Surna. 2014). Salah satu faktor yang mempengaruhi perkembangan bahasa anak SD ialah faktor lingkungan. Anak SD telah banyak belajar dari orang disekitar lingkungannya khususnya lingkungan keluarga yang merupakan lingkungan terdekat anak. Oleh karena itu, hendaknya orang tua dan masyarakat menggunakan istilahistilah bahasa yang lebih selektif dan lebih baik jika berada disekitar anak, karena pada dasarnya bahasa anak akan dipengaruhi oleh lingkungan tempat tinggalnya. (Adriana, 2008)

5. Perkembangan Moral keagamaan Lingkungan keluarga dan lingkungan sosial yang lebih luas di luar keluarga menjadi pusat dari pelajaran perkembangan moral bagi anak. Konsep perkembangan moral menjelaskan bahwa norma dan nilai yang ada dilingkungan sosial siswa akan mempengaruhi diri siswa untuk memiliki moral yang baik atau buruk (Trianingsih , 2016). Pada masa perkembangan kanak-kanak awal, moral anak belum berkembang pesat karena disebabkan oleh 
perkembangan kognitif anak yang belum mencapai pemahaman menganai prinsip benar salah menganai suatu hal, pada masa ini anak belum mampu membedakan hal-hal yang benar untuk dilakukan dan hal-hal yang tidak boleh dilakukan. (Murni, 2017). Berdasarkan periodesasi perkembangan Piaget, anak sekolah dasar kelas I, II, III, dan IV berada dalam periode transisi, yaitu meninggalkan periode moral realisme memasauki periode moral otonom. Akibat periode transisi itu tingkah laku moral anak kadang-kadang seperti tingkah laku moral anak periode heterenom dan kadangkadang seperti tingkah laku anak yang otonom. Bagi anak kelas II, III, dan IV yang masih berada dalam perkembangan moral heterenom, yaitu anak mulai melihat tingkah laku baik atau buruk yang dipanang dari akibat yang ditimbulkan oleh tingkah laku itu, dan bukan dari niat atau maksud si pelaku. Misalnya, ketika 12 buah gelas secara tidak sengaja dipecahkan oleh anak, hal ini akan dipandang anak sebagai tingkah laku yang lebih buruk dibandingkan dengan memecahkan sebuah gelas yang maksudnya untuk mencuri kue. Bagi anak yang dalam periode perkembangan moral otonom justru berpandang sebaliknya, bahwa memecahkan 12 buah gelas secara tidak sengaja lebih baik daripada memecahkan sebuah gelas karena ingin mencuri kue. Bagi anak itu kesalahan tingkah laku dilihat dari maksud orang bertingkah laku, bukan dari akibat yang ditimbulkan dari oleh tingkah laku itu. Sehubungan dengan aspek perkembangan moral anak, guru hendaknya dapat menanamankan moral pada anak yang dilakukan. tanpa disadari anak sehingga mendorong kesadaran dalam diri anak untuk berbuat sesuai dengan moral yang baik. (Trianingsih , 2016).

\section{Tugas Perkembangan Anak SD}

Havigurst mengatakan bahwa tugas perkembangan individu adalah tugas yang tampak pada suatu periode tertentu dalam kehidupan individu. Keberhasilan akan dapat memberikan kebahagiaan serta memberi kemudahan dalam menjalani tugas-tugas berikutnya, dan apabila gagal akan menimbulkan kekecewaan bagi individu tersebut, dan mengalami kesulitan untuk tugas perkembangan berikutnya. (Syaodih). Anak yang berada dalam rentang 6-12 tahun pada hakikatnya menjalani tugas perkembangan berupa kemampuan- 
kemampuan yang harus dikuasai anak sekolah dasar.

Havigusrt menjabarkan delapan tugas perkembangan anak pada periode usia 6-12 tahun. Delapan tugas perkembangan tersebut adalah sebagi beriku.

1. Belajar keterampilan fisik yang dibutuhkan dalam permainan

Selama waktu ini anak belajar menggunakan otot-ototnya untuk mempelajari brbagai keterampilan. Oleh karena itu , pertumbuhan otot dan tulang anak berlangsung dengan cepat. Mereka memiliki kebutuhan yang sangat tinggi untuk beraktivitas dan bermain. Mereka dapat melakukan permainan dengan aturan tertentu. Makin tinggi tingkat kelas anak di sekolah, makin jelas ciri khas aturan permainan yang harus mereka patuhi.

2. Pengembangan sikap terhadap diri sendiri sebagai individu yang sedang berkembang. Tugas perkembangan ini anak sudah paham dan mampu mengembangkan kebiasaan hidup sehat dengan membiasakan diri memelihara kebersihan, kesehatan, dan keselamatan diri serta lingkungannya atau mengetahui akibat yang akan didapatnya, jika mereka bertingkah laku yang dapat membahayakan

diri dan lingkungannya.

3. Berkawan dengan teman sebaya. Dengan masuknya anak kesekolah, akan menuntut anak untuk melakukan interaksi sosial dengan teman sebaya. Anak usia SD hendaknya sudah mampu berteman dengan orang lain di luar lingkungan keluarganya, khususnya teman sebaya sebagai bentuk interaksi sosial.

4. Belajar melakukan peranan sosial sebagai laki-laki dan wanita. Pada usia 9-10 tahun anak mulai menyadari peran sesuai dengan jenis kelaminnya. Anak perempuan menunjukkan tingkah laku sebagai perempuan, demikian pula dengan anak laki-laki. Pada masa ini anak sudah menunjukkan ketertarikan terhadap sesuatu sesuai dengan jenis kelamin mereka. Misalnya, anak perempuan senang bermain boneka dengan anak perempuan lainnya, dan anak laki-laki senang bermain bola dengan teman laki-lakinya.

5. Belajar menguasai keterampilan dasar membaca, menulis, dan berhitung. Masa ini anak SD sudah mampu untuk membaca dasar, menulis, dan berhitung. Karena perkembangan kognitif dan biologis anak sudah matang untuk bersekolah, 
maka anak telah mampu belajar di sekolah dan anak sudah mampu mengenali simbol-simbol sederhana.

6. Pengembangan konsep yang dibutuhkan dalam kehidupan anak. Pada masa ini anak hendaknya mempunyai berbagai konsep yang diperlukan dalam kehidupan seharihari. Seperti konseo warnam konsep jumlah konsep perbandingan dan lainnya

7. Pengembangan moral, nilai dan kata hati. Pada usia SD anak hendaknya diajar mengontrol tingkah laku sesuai nilai dan moral yang berlaku. Anak hendaknya dapat mentaati perauran, menerima tanggung jawab dan mengakui adanya perbedaan antara dirinya dan orang lain.

8. Mengembang sikap terhadap kelompok dan lembaga-lembaga sosial. Anak telah mampu belajar untuk menyadari keanggotaannya dalam keluarga dan masyarakat sekolah. Anak harus belajar mentaati peraturan-peraturan yang ada dalam keluarga dan sekolah (Prayitno, 2006).

\section{SIMPULAN}

Setiap anak usia sekolah dasar akan mengalami perkembangan secara fisik, kognitif, bahasa, sosio-emosional, bahasa, dan moral keagamaan yang berbeda-beda dalam cara dan waktu pencapaiannya.

Setiap anak memiliki kemampuan yang berbeda, sehingga seorang anak tidak boleh dipaksakan untuk memiliki aspek perkembangan yang sama dengan anak lain. Oleh karena itu guru dan orang tua hendaknya memiliki pengetahuan dalam usaha memaksimalkan aspek perkembangan anak karena, jika setiap aspek bisa berkembang dengan baik, maka anak mampu menjalankan tugas-tugas perkembangannya dengan baik pula.

\section{DAFTAR PUSTAKA}

Adriana, I. 2008. Memahami Pola Perkembangan Bahasa Anak Dalam Konteks Pendidikan. Jurnal Pendidikan Islam. Vol 3 No 1.

Havighurst, R.J. 1984. Perkembangan Manusia dan Pendidikan. Bandung: Jemmers

Harahap, N. 2014. Penelitian Kepustakaan. Jurnal Iqra'. Vol 8. No.1

Izzaty, R.E. 2008. Perkembangan Anak Usia 7-12 Tahun. Jurnal Pengabdian Universitas Negeri Yogyakarta.

Latifa, U. 2017. Aspek Perkembangan pada Anak Sekolah Dasar: Masalah dan Perkembangannya. Jurnal Academica. Vol 1. No.2. 
Murni. 2017. Perkembangan Fisik, Kognitif, Dan Psikososial Pada Masa Kanak-Kanak Awal 2-6 Tahun. Jurnal Ar raniry. Vol 3. No.1.

Prayitno, Elida. (2006). Buku Ajar Perkembangan Anak Usia Dini dan SD. Padang: Angkasa Raya

Sumantri, M. 2014. Modul 1 Pertumbuhan dan Perkembangan Anak. Jakarta: Universitas Terbuka

Slavin. 2011. Psikologi Pendidikan Teori dan Praktik. Jakarta: PT Indeks

Surna, I.N. (2014). Psikologi Pendidikan. Jakarta: Erlangga

Trianingsih, Rima. 2016. Pengantar Praktik Mendidik Anak Usia Sekolah Dasar. Jurnal Al Ibtida. Vol 3. No.2. 